\title{
PENGARUH INOVASI KEPALA SEKOLAH TERHADAP MOTIVASI KERJA GURU DI SMKN 9 MATARAM TAHUN PELAJARAN 2018/2019
}

\author{
Hardiansyah $^{1}$, Eka Mardianti ${ }^{2}$, Lu'luin Najwa ${ }^{3}$ \\ Administrasi Pendidikan FIP IKIP Mataram
}

Email: ekamardianti55@gmail.com

\begin{abstract}
Abstrak: Rumusan masalah dalam penelitian ini adalah : Apakah ada pengaruh inovasi kepala sekolah terhadap motivasi kerja guru di SMK Negeri 9 Mataram Tahun Pelajaran 2018/2019. Sedangkan tujuan penelitian ini adalah untuk mengetahui pengaruh inovasi kepala sekolah terhadap motivasi kerja guru di SMK Negeri 9 Mataram Tahun Pelajaran 2018/2019. Subjek dalam penelitian ini ditentukan dengan teknik populasi, jumlah populasi sebanyak 48 orang. Teknik pengumpulan data yang digunakan adalah metode angket sebagai metode pokok sedangkan metode dokumentasi sebagai metode pelengkap. Selanjutnya teknik analisis data yang digunakan adalah metode analisis statistik dengan rumus Regresi Linier Sederhana. Berdasarkan hasil analisis data diperoleh nilai $t_{\text {hitung }}$ sebesar 2,099 selanjutnya nilai tersebut dikonsultasikan dengan nilai $t_{\text {tabel }}$ sebesar 1,677 pada taraf signifikan $5 \%$ dengan $\mathrm{N}=48$. Kanyataan tersebut menunjukkan bahwa nilai $t_{\text {hitung }}$ lebih besar dari nilai $t_{\text {tabel }}$ atau 2,099 $>1,677$, maka hasil analisis data dalam penelitian ini dinyatakan Signifikan. Dengan demikian dapat disimpulkan bahwa "Ada Pengaruh Inovasi Kepala Sekolah Terhadap Motivasi Kerja Guru Di SMK Negeri 9 Mataram Tahun Pelajaran 2018/2019". Dari hasil penelitian tersebut, dapat disimpulkan bahwa inovasi kepala sekolah berperan dalam meningkatkan motivasi kerja guru di sekolah. Inovasi yang dilakukan kepala sekolah membuat para guru termotivasi bekerja lebih aktif dan selalu ingin meningkatkan hasil kerjanya. Dari hasil penelitian ini terdapat hal-hal yang baik yaitu kepala sekolah mampu mendorong guru agar lebih semangat dan memiliki tanggung jawab dalam pekerjaannya. Diharapkan hasil penelitian ini dapat dijadikan sebagai salah satu bahan pertimbangan bagi peneliti lain untuk melakukan penelitian yang lebih dalam lagi terhadap aspek-aspek yang masih kurang yaitu kepala sekolah dalam membimbing para guru mengembangkan bahan ajar dan guru yang belum puas dengan gaji yang diterimanya sebagai guru.
\end{abstract}

\section{Kata kunci : Inovasi Kepala Sekolah, Motivasi Kerja Guru}

\section{PENDAHULUAN}

Pendidikan adalah pembelajaran, keterampilan dan kebiasaan sekelompok orang yang diturunkan dari satu generasi ke generasi berikutnya melalui pengajaran, pelatihan atau penelitian.

Pemegang peran yang sangat penting dalam lembaga pendidikan yaitu kepala sekolah. Kepala sekolah selalu mengikuti perkembangan yang ada selama hal tersebut membawa dampak positif dalam perkembangan sekolah sesuai tujuan yang diharapkan. Oleh karena itu, dibutuhkan suatu inovasi yang dilakukan oleh kepala sekolah. Inovasi adalah suatu ide, barang, kejadian, metode yang dirasakan atau diamati sebagai suatu hal 
yang baru bagi seseorang atau kelompok orang baik itu merupakan hasil invention maupun discoveri”.

Kepala sekolah adalah guru yang mendapat tambahan tugas sebagai kepala sekolah. Sebagai kepala sekolah dituntut untuk memikirkan perkembangan pendidikan di sekolah tersebut. Kepala sekolah seharusnya orang yang memiliki kecerdasan, kekreatifan, dan visi dan tujuan ke depan dalam rangka menatap realitas yang semakin maju. Kepala sekolah adalah agen pembaharu, sangat penting dalam inovasi pendidikan. Tugas pokok dalam inovasi pendidikan adalah menilai efektivitas program, mengkaji, mengembangkan dan mengimplementasikan program pengembangan sekolah.

Misalnya dari faktor kebutuhan guru yaitu sarana dan prasarana sekolah untuk dapat mengembangkan kreativitasnya serta bantuan yang diberikan oleh kepala sekolah dalam memfasilitasi, terjalinnya hubungan yang harmonis, dan adanya suatu tekanan dari kepala sekolah agar para guru dapat lebih bertaggung jawab dalam pekerjaannya. Dengan adanya faktor-faktor diatas guru dapat menjalankan pekerjaannyaanya dengan lancar dengan penuh motivasi. Robbins (2006) Motivasi merupakan proses yang ikut menentukan itensitas, arah, dan ketekunan individu dalam usaha mencapai sasaran.

Berdasarkan hasil observasi, adapun permasalahan yang terjadi di SMKN 9 Mataram antara lain : 1) Kurang adanya pengembangan inovasi dalam pembelajaran, 2) Belum dapat mengembangkan professional serta motivasi guru dan tenaga kependidikan, 3) Kurang meningkatkan lingkungan sekolah yang kondusif, 4) Kurang adanya daya tahan guru tehadap tekanan yang di berikan kepala sekolah 5) Adanya kebutuhan guru yang masih belum terpenuhi.

KAJIAN PUSTAKA

\section{Inovasi Kepala Sekolah}

Ibrahim (1988) "inovasi pendidikan adalah suatu ide, barang, metode, yang dirasakan atau diamati sebagai sesuatu hal yang baru bagi seseorang atau sekelompok orang (masyarakat), baik berupa hasil invensi maupun diskoveri untuk mencapai tujuan pendidikan atau memecahkan masalah pendidikan".

Sa'ud (2008), "inovasi (innovation) ialah suatu ide, barang, kejadian, metode yang dirasakan atau diamati sebagai suatu hal yang baru bagi seseorang atau sekelompok orang (masyarakat), baik itu berupa hasil invention maupun discovery. Inovasi diadakan untuk mencapai tujuan tertentu atau untuk memecahkan suatu masalah".

Jadi menurut pendapat di atas disimpulkan bahwa inovasi kepala sekolah adalah suatu ide, barang, metode yang diamati atau dirasakan oleh kepala sekolah sebagai hal yang baru untuk tujuan tertentu.

\section{Motivasi Kerja Guru}

Hasibudin (Damayanthi,2015) menyatakan bahwa motivasi itu sendiri ialah pemberian daya penggerak agar mendorong seseorang untuk bekerja sama, bekerja efektif dan terintegrasi dengan segala daya dan upayanya untuk mencapai kepuasan. Muhlison (2014) guru merupakan faktor penting dan utama dalam proses pendidikan, karena guru adalah orang yang bertanggungjawab terhadap perkembangan jasmani dan rohani peserta didik.

Jadi dapat disimpulkan bahwa motivasi kerja adalah suatu dorongan kerja bagi guru untuk melaksanakan tugas dan tanggungjawabnya dengan baik sesuai dengan tujuan yang telah ditetapkan.

\section{Kerangka Berfikir}

Inovasi adalah suatu karya cipta manusia yang dilahirkan melalui ide atau gagasan yang merupakan pengembangan 
suatu hal yang baru yang dapat diamati dan dilaksanakan secara sistematis dalam mencapai tujuan tertentu dan dalam rangka untuk memecahkan masalah yang ada.

Untuk itu perlu adanya suatu inovasi dari kepala sekolah agar menumbuhkan motivasi dalam diri guru untuk bekerja lebih efektif dan efisien serta seorang guru dapat lebih bertanggung jawab dalam melakukan pekerjaannya. Karena guru merupakan komponen yang paling berpengaruh terhadap terciptanya proses dan hasil pendidikan yang berkualitas.

Seorang kepala sekolah mendorong atau memberikan motivasi kepada guru dan tenaga kependidikan dan merupakan wujud kepala sekolah sebagai inovator yang dilakukan oleh kepala sekolah. Mulyasa (2005) "menjelaskan peran kepala sekolah yaitu sebagai innovator, yang harus memiliki stategi yang tepat untuk mencari gagasan baru serta mengembangkan model-model pembelajaran yang inovatif dan secara langsung kepala sekolah dapat sebagai motivator untuk para guru, motivasi ditumbuhkan melalui pengaturan lingkungan fisik, pengaturan suasana kerja, disiplin, dorongan, penghargaan secara efektif'.

Hal ini dapat dipahami bahwa pimpinan atau kepala sekolah adalah top leader dari suatu lembaga pendidikan. Sebagai pemimpin harus memberikan hal yang terbaik bagi pengembangan dan meningkatkan kualitas pendidikan terutama memotivasi para guru untuk bekerja lebih baik lagi.

Sehubungan dengan penelitian ini, teknik pengumpulan data yang digunakan adalah metode angket. Kemudian datadata yang sudah dikumpulkan, dianalisis agar bermanfaat untuk menjawab masalah penelitian. Teknik analisis data yang digunakan adalah teknik analisis statistik dengan rumus Regresi Linier Sederhana. Hasil analisa data kemudian ditindak lanjuti dalam bentuk laporan hasil penelitian, sebagai jawaban akhir dari masalah akhir dari masalah yang telah dirumuskan sebelumnya.

\section{METODE PENELITIAN}

Menurut Sudjana dan Ibrahim (2004), "Rancangan penelitian merupakan keseluruhan proses pemikiran dan penentu jelas tentang hal-hal yang dilakukan serta dapat dijadikan besar penelitian dan mempertanggung jawabkan terhadap semua langkah-langkah yang diambil. Rancangan penelitian adalah suatu pendekatan yang digunakan dalam suatu penelitian. Dalam penelitian ini terdapat dua variabel, yaitu Variabel $\mathrm{X}$ disebut variable bebas (Indepen denvariabel) adalah "Inovasi Kepala Sekolah" dan Variabel Y disebut variabel terikat (dependent variabel) adalah "Motivasi Kerja Guru".

Teknik pengumpulan data dari penelitian ini menggunakan metode angket dan observasi serta teknik analisis data menggunakan rumus Regresi Linier Sederhana, dari hasil analisis data tersebut kemudian akan ditarik kesimpulan sebagai hasil dari penelitian. Dalam rancangan penelitian ini yang digunakan adalah penelitian kuantitatif atau statistik untuk memperoleh data yang lebih spesifik, jelas, rinci, ditentukan secara mantap sejak awal dan menjadi pegangan langkah demi langkah melalui angket. Oleh karena itu, peneliti membuat rancangan penelitian terkait dengan "Pengaruh Inovasi Kepala Sekolah Terhadap Motivasi Kerja Guru" dengan indikator pada masing-masing variabel.

Berdasarkan rancangan penelitian di atas maka dapat dibuat desain penelitian secara konseptual sebagai berikut :

Variabel Bebas (X)

Inovasi Kepala Sekolah
Variabel Terikat (Y)

Motivasi Kerja Guru 


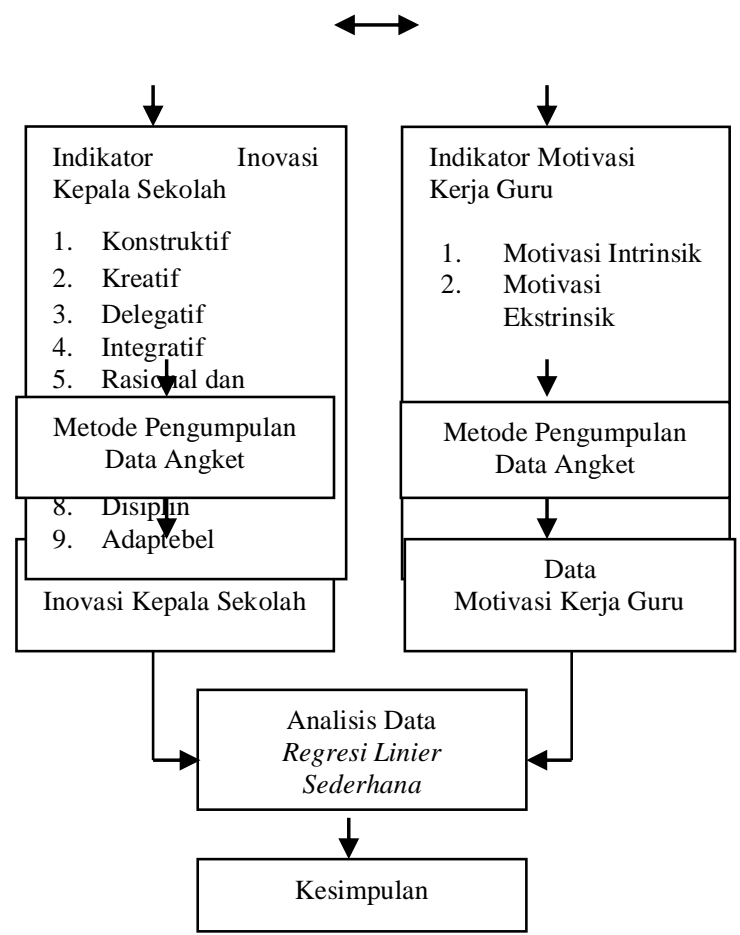

Adapun yang menjadi populasi subjek dalam penelitian ini adalah seluruh guru di SMK Negeri 9 Mataram yang berjumlah 48 orang. Sedangkan yang menjadi objek dalam penelitian ini adalah Inovasi Kepala Sekolah Terhadap Motivasi Kerja Guru di SMKN 9 Mataram Tahun Pelajaran 2018/2019.

Sehubungan dengan penelitan ini, teknik analisa data yang digunakan adalah teknik analisis statistik dengan rumus Regresi Linier Sederhana. Dengan rumus:

$$
\mathrm{Y}=\mathrm{a}+\mathrm{bX}
$$

Keterangan :

Y: Subjek variabel terikat/dependen $\mathrm{X}$ : Variabel bebas a : Intersep/ satuan bilangan konstanta $\mathrm{b}$ : Koefisien regresi variabel terikat

\section{HASIL DAN PEMBAHASAN}

Adapun hasil penelitiannya, diawali dengan mendapatkan dokumen nama-nama guru di SMKN 9 Mataram. Data yang dibutuhkan dalam penelitian ini adalah data tentang Pengaruh Inovasi Kepala Sekolah Terhadap Motivasi Kerja Guru di SMKN 9 Mataram tahun pelajaran 2018/2019 yang didapat melalui tiga tahap yaitu: a) Menyebar angket kepada guru, b) Penarikan angket, c) Menganalisa skor angket dengan rumus regresi linier sederhana. Dalam menganalisis data dalam penelitian ini beberapa tahap yang dilalui yaitu:

\section{a. Melakukan Uji Validitas}

Uji validitas dilakukan untuk mengukur apakah semua item pernyataan yang telah diajukan valid atau tidak. Untuk validitas instrumen dilakukan dengan melihat korelasi atau skor masingmasing item pernyataan. Peneliti menggunakan software program SPSS (statistical product and service solution), dan dihitung dengan rumus korelasi product moment sebagai berikut:

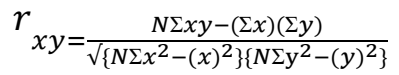

Keterangan :

$\mathrm{X}$ : Skor butir

Y : Skor total yang diperoleh

$\mathrm{N}$ : Jumlah responden

b. Melakukan Uji Reliabilitas

Kuesioner dikatakan reliable jika jawaban seseorang terhadap pernyataan adalah konsisten atau stabil dari waktu ke waktu. Untuk mengetahui alat ukur yang dipalkai reliable dengan menggunakan rumus koefesien reliabelitas alpha crombach, dengan rumus :

$$
r_{\iota j}=\left\{\frac{k}{k-1}\right\}\left\{1-\frac{\Sigma \sigma b^{2}}{\Sigma \sigma b^{2}}\right\}
$$


Keteranga :

$r_{\imath j}$ : reliabilitas instrument

$k$ : Banyak butir soal atau pertanyaan

$\Sigma \sigma \mathrm{xb}^{2}$ : jumlah varian butir $\Sigma \sigma \mathrm{b}^{2}=$ variasi total

Untuk menguji signifikasi nilai cronbach alpha berdasarkan hasil analisis itu dibandingkan dengan nilai koefesien cronback alpha tabel pada taraf signifikansi $\alpha$ adalah 0,05 (5\%). Instrumen dikatakan konsisten (reliable) apabila nilai cronbach alpha lebih kecil dari 0,05 maka instrumenttersebut tidak reliable (konsisten).

c. Uji Deskriptif Data Inovasi Kepala Sekolah dan Motivasi Kerja Guru

1) Uji deskriptif Inovasi Kepala Sekolah

\begin{tabular}{|l|r|r|r}
\hline & $\begin{array}{r}\text { Inovasi } \\
\text { Kepala } \\
\text { Sekolah }\end{array}$ & Persentase & Kategori \\
\hline N $\quad$ Valid & 48 & 48 & 48 \\
Mean & 0 & 0 & 0 \\
Median & 77.63 & 77.63 & \\
Mode & 77 & 77 & \\
Std. Deviation & $76(\mathrm{a})$ & $76(\mathrm{a})$ & \\
Variance & 6.327 & 6.327 & \\
Range & 40.027 & 40.027 & \\
Minimum & 29 & 29 & \\
& 64 & 64 & \\
Maximum & 93 & 93 & \\
\hline
\end{tabular}

Tabel output di atas dapat disimpulkan bahwa jumlah pengukuran $(\mathrm{N})=48$, yang menunjukkan data valid dengan rata-rata (mean) 77,63, nilai median 77,00 , nilai modus 76 , standar deviasi 6,327, nilai varian 40,027, nilai rentang 29, nilai minimum 64 dan nilai maximum 93.

Untuk mengetahui kondisi variabel inovasi kepala sekolah, maka penulis melakukan pengukuran dengan menggunakan kuesioner yang terdiri dari 25 pernyataan dan masing-masing disertai dengan 4 alternatif jawaban. Berikut adalah grafik pengukuran kepemimpinan partisipatif :

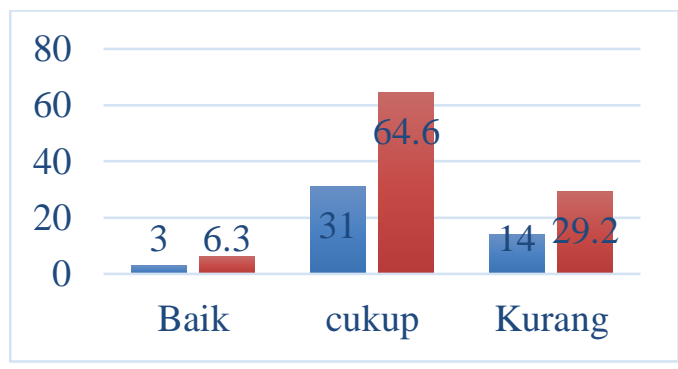

Keterangan:

$\square$ : Jumlah Responden

: Presentase Penilaian

Penilaian dalam penelitian ini terbagi menjadi 3 kategori, yaitu baik, cukup, dan kurang. Dari grafik di atas dapat disimpulkan bahwa terdapat 3 responden dengan persentase 6,3\% memberikan penilaian baik, 31 responden dengan persentase $64,6 \%$ memberikan penilaian cukup, dan 14 responden dengan persentase 29,2\% memberikan penilaian kurang. Dari hasil tersebut, dapat disimpulkan bahwa inovasi kepala sekolah telah dilaksanakan dengan cukup baik, karena dari $100 \%$, ada $64,6 \%$ responden memberi jawaban cukup.

2) Uji deskriptif Motivasi Kerja Guru 


\begin{tabular}{|l|r|r|r|}
\hline & $\begin{array}{c}\text { Motivasi } \\
\text { Kerja } \\
\text { Guru }\end{array}$ & Persentase & Kategori \\
\hline N $\quad$ Valid & 48 & 48 & 48 \\
Mean $\quad$ Missing & 0 & 0 & 0 \\
Median & 75.19 & 75.19 & \\
Mode & 75 & 75 & \\
Std. Deviation & 76 & 76 & \\
Variance & 5.999 & 5.999 & \\
Range & 35.985 & 35.985 & \\
Minimum & 39 & 39 & \\
Maximum & 58 & 58 & \\
\hline
\end{tabular}

Tabel output di atas menjelaskan tentang jumlah pengukuran $(\mathrm{N})=48$ yang menunjukkan data valid dengan rata-rata (mean) 75,19 , nilai median 75,00 , nilai modus 76, standar deviasi 5,999, nilai varian 35,985 , nilai rentang 39 , nilai minimum 58 dan nilai maximum 97.

Untuk mengetahui kondisi variabel kinerja pegawai, maka penulis melakukan pengukuran dengan menggunakan kuesioner yang terdiri dari 24 pernyastaan. Berikut adalah grafik pengukuran kineja pegawai:

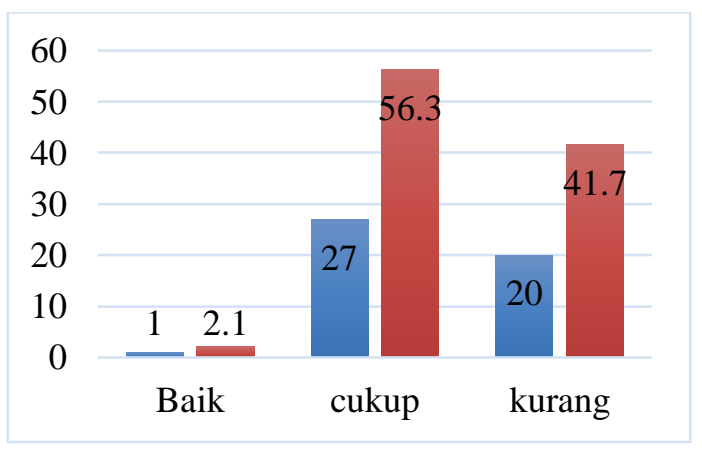

Keterangan:
$\square$ : Jumlah Responden
: Presentase Penilaian

Dari grafik tersebut dapat disimpulkan bahwa terdapat 1 responden $(2,1 \%)$ memberikan penilaian baik, 27 responden $(56,3 \%)$ memberikan penilaian cukup, dan 20 responden $(41,7 \%)$ memberikan penilaian kurang. Berdasarkan hasil tersebut, dapat disimpulkan bahwa kondisi kinerja pegawai cukup baik, karena dari $100 \%$, ada $56,3 \%$ yang memberi penilaian cukup dengan jumlah responden sebanyak 27.

d. Uji Normalitas dengan uji Kolmogorow-Smirnov

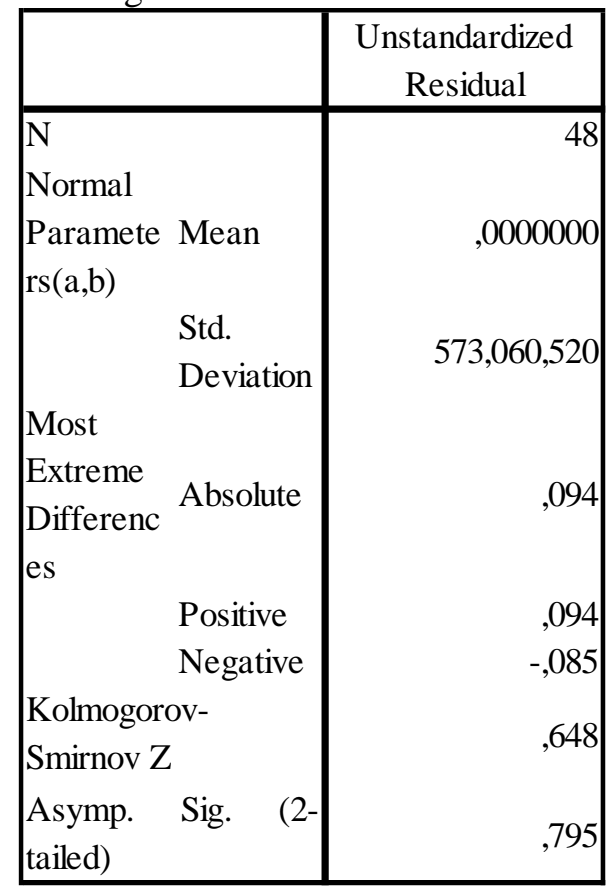

Berdasarkan tabel Uji Normalitas, diketahui nilai signifikansi Asymp.Sig (2tailed) sebesar 0,795 lebih besar dari 0,05. Maka sesuai dengan keputusan Asymp Sig (2-tailed) dapat disimpulkan bahwa data berdistribusi normal. 
e. Uji Persamaan Regresi

\begin{tabular}{|c|c|c|c|c|c|c|}
\hline \multirow[t]{2}{*}{ Model } & & \multicolumn{2}{|c|}{$\begin{array}{l}\text { Unstandardized } \\
\text { Coefficients }\end{array}$} & \multirow{2}{*}{$\begin{array}{c}\begin{array}{c}\text { Standardi } \\
\text { zed } \\
\text { Coefficie } \\
\text { nts }\end{array} \\
\text { Beta }\end{array}$} & \multirow[t]{2}{*}{$\mathrm{T}$} & \multirow{2}{*}{$\begin{array}{c}\text { Sig. } \\
\text { Std. Error }\end{array}$} \\
\hline & & B & Std. Error & & & \\
\hline \multirow{4}{*}{1} & (Constant) & 53.427 & 10.401 & & 5.137 & \\
\hline & Inovasi & & & & & \\
\hline & Kepala & 0.28 & 0.134 & 0.296 & 2.099 & 0.041 \\
\hline & Sekolah & & & & & \\
\hline
\end{tabular}

Tabel persamaan regresi memberikan keterangan hasil analisis regresi linier sederhana dengan menggunakan SPSS 15 memberikan hasil persamaan regresi sebagai berikut $\mathrm{Y}=\mathrm{a}+$ bX atau $\mathrm{Y}=53,427+0,280 \mathrm{X}$. Dengan persamaan regresi tersebut, dapat diprediksi berapa skor inovasi kepala sekolah setelah mengetahui skor motivasi kerja guru. Jadi jika tidak ada inovasi kepala sekolah, maka prediksi terhadap skor motivasi kerja guru adalah 53,427. Koefisien regresi $\mathrm{X}$ sebesar 0,280 menyatakan bahwa setiap penambahan 1 nilai inovasi kepala sekolah, maka nilai kinerja bertambah sebesar 0,28.

f. Menentukan tingkat keeratan hubungan (korelasi) antar X dan Y

\begin{tabular}{|c|c|c|c|}
\hline & & $\begin{array}{l}\text { Inovasi } \\
\text { Kepala } \\
\text { sekolah }\end{array}$ & $\begin{array}{l}\text { Motivasi } \\
\text { kerja guru }\end{array}$ \\
\hline $\begin{array}{l}\text { Inovasi } \\
\text { Kepala } \\
\text { sekolah } \\
\text { Motivasi } \\
\text { kerja guru }\end{array}$ & $\begin{array}{l}\text { Pearson } \\
\text { Correlatio } \\
\mathrm{n} \\
\text { Sig. (2- } \\
\text { tailed) } \\
\mathrm{N} \\
\text { Pearson } \\
\text { Correlatio } \\
\mathrm{n} \\
\text { Sig. (2- } \\
\text { tailed) } \\
\mathrm{N}\end{array}$ & $\begin{array}{r}48 \\
, 296(*) \\
0,041\end{array}$ & $\begin{array}{r}, 296(*) \\
0,041 \\
48 \\
1\end{array}$ \\
\hline
\end{tabular}

Output analisis di atas menunjukkan bahwa korelasi variabel $\mathrm{X}$ dan $\mathrm{y}$ sebesar 0,296 dengan taraf signifikan 0,041. Karena taraf signifikan yang diperoleh lebih kecil dari 0,05 maka keputusan yang diambil adalah bahwa korelasi antara $\mathrm{X}$ dan $\mathrm{Y}$ merupakan korelasi yang signifikan.

g. Menentukan besar pengaruh variabel bebas terhadap variabel terikat

\begin{tabular}{|l|c|l|l|l|}
\multicolumn{1}{|c|}{ Model Summary } \\
Model & R & R Square & $\begin{array}{c}\text { Adjusted } \\
\text { R Square }\end{array}$ & $\begin{array}{c}\text { Std. Error } \\
\text { of the } \\
\text { Estimate }\end{array}$ \\
\hline 1 &, $296($ a) &, 87 & 0,67 & 5,793 \\
\hline
\end{tabular}

Tabel di atas menunjukkan bahwa nilai koefisien determinasi (R) yang diperoleh adalah sebesar $8,7 \%$. Berdasarkan hasil ini maka besar pengaruh dari faktor atau variabel lain yang tidak diteliti sebesar $91,3 \%$.

h. Signifikansi model regresi atau signifikansi pengaruh variabel bebas terhadap variabel terikat

\begin{tabular}{|rr|r|r|r|r|l|}
\hline Model & & $\begin{array}{r}\text { Sum of } \\
\text { Squares }\end{array}$ & Df & $\begin{array}{r}\text { Mean } \\
\text { Square }\end{array}$ & F & Sig. \\
\hline & Regression & 147.84 & 1 & 147.84 & 4.406 & $.041(\mathrm{a})$ \\
1 & & & & & \\
& Residual & 1543.472 & 46 & 33.554 & & \\
& Total & 1691.313 & 47 & & & \\
\hline
\end{tabular}

Signifikan model regresi dan pengaruh variabel bebas ditentukan oleh nilai $F_{\text {hitung }}$ dan taraf signifikannya. Jika taraf signifikan yang diperoleh lebih kecil dari 0,05 maka keputusan yang diambil adalah model regresi dan pengaruh variabel bebas adalah signifikan. Output analisis menunjukkan bahwa nilai $F_{\text {hitung }}$ adalah sebesar 4,406 dengan taraf signifikan 0,041. Karena taraf signifikan 
yang diperoleh lebih kecil dari 0,05 maka keputusan yang diambil:

1) Hasil prediksi terhadap variabel terikat berdasarkan model regresi linier sederhana $\mathrm{Y}=\mathrm{a}+\mathrm{bX}$ adalah prediksi yang dapat dipercaya (Akurat).

2) Pengaruh $X$ terhadap $Y$ yang sebesar $8,7 \%$ merupakan pengaruh yang signifikan.

i. Menentukan signifikan pengaruh variabel bebas terhadap veriabel terikat $\rightarrow \mathrm{t}$ hitung

\begin{tabular}{|c|c|c|c|c|c|c|}
\hline \multirow[t]{2}{*}{ Model } & & \multicolumn{2}{|c|}{$\begin{array}{l}\text { Unstandardized } \\
\text { Coefficients }\end{array}$} & \multirow{2}{*}{\begin{tabular}{|c|}
$\begin{array}{c}\text { Standardi } \\
\text { zed } \\
\text { Coefficie } \\
\text { nts }\end{array}$ \\
Beta \\
\end{tabular}} & \multirow{2}{*}{$\begin{array}{l}\mathrm{T} \\
\mathrm{B}\end{array}$} & \multirow{2}{*}{\begin{tabular}{|c|} 
Sig. \\
Std. Error
\end{tabular}} \\
\hline & & B & Std. Error & & & \\
\hline \multirow{4}{*}{1} & (Constant) & 53.427 & $\overline{10.401}$ & & 5.137 & \\
\hline & Inovasi & & & & & \\
\hline & Kepala & 0.28 & 0.134 & 0.296 & 2.099 & 0.041 \\
\hline & Sekolah & & & & & \\
\hline
\end{tabular}

Diketahui nilai $t_{\text {hitung }}$ sebesar 2,099 nilai $t_{\text {tabel }}$ sebesar 1,677 dengan taraf signifikan 0,05 maka dapat disimpulkan kedua variabel terdapat pengaruh (signifikan).

j. Pengujian Hipotesis

Berdasarkan hasil analisis data pada output Coofetients, diketahui nilai $t_{\text {hitung }}$ sebesar 2,099. Selanjutnya, nilai tersebut dikonsultasikan dengan nilai $t_{\text {tabel }}$ pada taraf signifikansi 0,05 dengan $\mathrm{N}=48$, maka diperoleh nilai $t_{\text {tabel }}$ sebesar 1,677 . Kenyataan tersebut menunjukkan bahwa $t_{\text {hitung }}$ lebih besar dari nilai $t_{\text {tabel }}$ atau 2,099> 1,677. Dengan demikian, hasil analisis data dalam penelitian ini dinyatakan signifikan. Dan dengan demikian, hipotesis nihil
(Ho) ditolak, sedangkan hipotesis alternatif (Ha) diterima.

\section{KESIMPULAN DAN SARAN}

\section{A. KESIMPULAN}

Berdasarkan hasil analisis statistik regresi linier sederhana pengujian hipotesis dalam penelitian ini diketahui bahwa nilai $t_{\text {hitung }}$ lebih besar dari $t_{\text {tabel }}$ pada taraf signifikan 0,05 dengan jumlah $\mathrm{N}=48$ orang, atau ( $t_{\text {hitung }} 2,099>t_{\text {tabel }}$ $1,677)$ yang berarti hasil penelitian ini adalah signifikan, dengan demikian dapat ditarik kesimpulan bahwa "Pengaruh Inovasi Kepala Sekolah Terhadap Motivasi Kerja Guru di SMK Negeri 9 Mataram Tahun Pelajaran 2018/2019" terdapat pengaruh sebesar 0,087. Dari hasil tersebut, dapat ditarik kesimpulan sesuai dengan Tabel Interpretasi Product Moment bahwa pengaruh kedua variabel berada dalam kategori sangat rendah. Oleh karena itu, inovasi kepala sekolah dapat mengembangkan bahan ajar, memberikan gagasan dan ide-ide baru terkait proses pembelajaran dan mengembangkan inovasi kreatif yang dapat dituangkan kepada para guru.

\section{B. SARAN}

Berdasarkan hasil penelitian yang telah dilakukan, ada beberapa saran yang dapat diberikan, yaitu:

1. Bagi kepala sekolah, hasil penelitian ini dapat memberikan kontribusi pemikiran bagi kepala sekolah untuk mengembangkan inovasi yang kreatif sebagai upaya memotivasi para guru.

2. Bagi guru, diharapkan hasil penelitian ini dapat digunakan sebagai masukan dalam menjalankan tugas dengan penuh tanggungjawab dan lebih termotivasi untuk bekerja lebih baik. 
3. Hasil penelitian ini juga dapat dijadikan sebagai salah satu bahan pertimbangan bagi peneliti lain untuk melakukan penelitian yang lebih terhadap aspek-aspek yang belum terungkap dan masih kurang dalam penelitian ini.

\section{DAFTAR PUSTAKA}

Damayanthi. 2015. Hubungan Antara Stress Kerja dan Motivasi Kerja dengan Kinerja Karyawan. Persona, Jurnal Psikologi Indonesia, 4 (01).

Ibrahim. 1998. Inovasi Pendidikan. Jakarta : Depdikbud Dikti, Proyek Pengembangan Tenaga Kependidikan.

Muhlison. 2014. Guru Profesional (Sekolah Karakteristik Guru Ideal Dalam Pendidikan Islam). Jurnal Darul Ilmi. Vol 02. No. 02.

Mulyasa. 2005. Menjadi Guru Profesional. Bandung : PT Remaja Rosdakarya.

Robbins S P. 2006. Perilaku Organisasi(Edisi

Kesepuluh). Jayakarta : PT. Macanan Jaya Cemelang.

Sa'ud. 2008. Inovasi Pendidikan. Bandung : Alfabeta.

Sudjana., Ibrahim. 2004. Penelitian Dan Penilaian Pendidikan. Bandung: Sinar Baru Algesindo. 